and the annual report of the Society's scientific officers and of its research committee. Each part will include a summary of the proceedings of the Council at its meetings in the previous two or three months and will be separately indexed. The June issue for 1939 (100, Part 1$)$ is now available and can be obtained from the Society, 16 -Bedford Square, W.C.1, prico $5 s$.

\section{The Grid System}

THE Association of Engineering and Shipbuilding Draughtsmen publishes (Draughtsman Publishing Co., Ltd., 96 St. Georgo's Square, London, S.W.I) a series of pamphlets containing much useful information. A recent issue, entitled "The Grid System", contains a historical survey of electricity supply in Great Britain from the formation of the Fdison Light Co. in London in 1881, through the troublous years when various Acts of Parliament were passed which in some cases hampered the industry; the first contracts for the 'grid-iron' or grid system were placed in the year 1928, and this was followed by the growth in the space of six years of 4,000 miles of transmission lines and the placing of 26,000 steel pylons. The advantages of standardizing frequency are discussed and the systems adopted for grid tariffs and trading. Much of the information is not readily obtainable elsewhere. A list is included of A.E.S.D. printed pamphlets and other publications written specially for engineering and shipbuilding draughts. men.

\section{Dutch Colonial Institute}

TuE "Acht en Twintigste Jaarverslag van het Koloniaal Instituut" gives a brief account of the work of the Dutch Colonial Institute at Amsterdam during the year 1938. Its activities have included public lectures, courses of instruction in tropical hygiene, researches on tropical diseases such as yellow fever and psittacosis, studies in mosquito control and the chemical examination of more than four thousand samples. The valuable work recorded in this year-book gives ample evidence that the Dutch Colonial Institute continues actively to servo the interests of Holland and its oversea possessions.

\section{The Scientific Films Committee}

ABout two years ago the Association of Scientific Workers set up a Scientific Films Committee, to act as a clearing-house of information on scientific films. During this time it has seen and appraised some 150 films, and has produced a graded list of these films with particulars of length, availability, subject-matter, distributor, etc. This list is available to anyone interested at a cost of $1 s$. If desired, the Committee will undertake, for a small charge, to choose a programme to suit any particular requirements. In addition, the Committee has compiled an index of scientific and film experts willing to be put in touch with people requiring advice on the making of films. Full particulars of the services offered can be obtained from the Secretary, Scientific Films Committee, 30 Bedford Row, London, W.C.1.

\section{Apparatus for the Physical Laboratory}

Tre twenty-fifth edition of the catalogue of physical laboratory apparatus and equipment recently issued by Messrs. W. and J. George, Ltd., proprietors of F. E. Becker and Co., London and Birmingham, is an impressive volume of 824 pages. The contents cover the whole of the equipment needed for the teaching of physics in all types of educational institution from elementary school to university. For convenience of reference, the catalogue is classified into thirteen sections within which the items are arranged in the usual text-book order of treatment of the subject. Physics is divided into ten sections. Tho remaining three deal with laboratory fittings, equipment and materials, with lantorn slides, ciné films and with text-books. Out-of-date items have been entirely replaced by new apparatus, and the designs of many standard instruments have been improved. In addition to the well-known series of Nivoc products made by Messrs. Georgo, other British and foreign items are included so that every normal requirement in physies teaching is to be found within the covers. But it is more than a mere catalogue. Each item dealing with less well-known apparatus has a brief description of the method of use, together with the necessary theory, supplemented in some of the entries by typical numerical results obtained with the apparatus in the laboratory. Some of theso descriptions cover a page or two. The specially drawn illustrations are very clear and project well in the epidiascope. Altogether the catalogue, with its detailed index, corner page headings and numerous cross-references, makes a noteworthy addition to the library of any educational or industrial physics laboratory.

\section{Book Reviews}

SIDE by side with the increase in numbers of scientific papers which has been referred to repeatedly in this journal in recent years, there has been a steady if smaller growth of scientific and technical text-books, monographs and other books of interest to readers of NATURE, and the task of presenting to the scientific reader a reasoned survey of such literature has become increasingly difficult in the limited space available. Following the customary practice, longer notices of books have been printed under appropriate titles, while shorter notices have been brought together without a special heading; in addition, a classified list of recent scientific and technical books, whether received for notice in NAture or not, is printed every month as a supplement to the journal. In the present issue, the shorter notices, which used to appear in the body of the journal immediately after the longer reviews, have been placed in the supplement with the books list. By publishing these shorter notices once a month in this way, it is possible to arrange them according to subject and it is also hoped to increase the total amount of space given to such notices. For the convenience of those who wish to bring the books lists together when binding up a volume, the list 
has been arranged as usual in the middle of the supplement, the pagination of which will be unaffected by its removal.

\section{American Geographical Society Awards}

Accordeng to Science, the American Geographical Society has made the following awards : Cullum Geographical Medal for 1938 to Emmanuel de Martonne, professor of geography at the University of Paris; Charles P. Daly Medal for 1939 to Prof. H. J. Fleure, professor of geography in the University of Manchester; David Livingstone Centenary Medal for 1939 to John R. Rymill, in recognition of his scientific achievement and exploration in the southern hemisphere. The following have been made honorary members of the Society: Sir Wilfred Grenfell, for his contributions to geographical knowledge concerning the Labrador Peninsula; Prof. H. Baulig, professor of geography in the University of Strasbourg, and Prof. G. Dainelli, professor of geology and physical geography in the University of Florence. The following have been made corresponding members of the Society: E. Antevs, research associato of the Carnegie Institution of Washington; Prof. L. L. Mecking, professor of geography at the University of Münster; W. E. Rudolph, a civil engineer who has carried out extensive explorations in South America; P. G. Schott, retired section chief of the Deutsche Seewarte and honorary professor in the University of Hamburg, and Dr. L. Dudley Stamp, reader in economic geography in the University of London and director of the Land Utilization Survey of Great Britain.

\section{The Night Sky in August}

Tire moon is new on August 15 at $3 \cdot 9 \mathrm{~h}$. U.T. and full on August 29 at $22 \cdot 1 \mathrm{~h}$. On August 25, p Sagittarii (magnitude $4 \cdot 0$ ) is occulted, the disappearance as seen from Greenwich taking place at $23 \mathrm{~h} .48 \cdot 9 \mathrm{~m}$. at position angle $77^{\circ}$ from the north point of the moon's disk. Conjunctions between moon and planets occur as follows: August 5d. 14h. with Jupiter; 7d. 9h. with Saturn; 26d. 14h. with Mars. On August 25 at $20 \mathrm{~h}$. Venus is in conjunction with Regulus, the geocentric distance between the planet and the star being $0 \cdot 9^{\circ}$. Mars, Jupiter and Saturn rise in the evening, the respective times of southing on August 1 being $23 \mathrm{~h} .23 \mathrm{~m} ., 3 \mathrm{~h}$. $55 \mathrm{~m}$., and $5 \mathrm{~h} .20 \mathrm{~m}$.; by August 25 these times have changed to $21 \mathrm{~h} .35 \mathrm{~m}$., $2 \mathrm{~h}$. $17 \mathrm{~m}$. and $3 \mathrm{~h} .46 \mathrm{~m}$. Mars, a conspicuous object low in the evening sky, declines in brightness during the month from mag. -2.5 to -1.8 ; Jupiter increases slightly from mag. $-2 \cdot 3$ to $-2 \cdot 4$. Nercury reaches its greatest western elongation $\left(18^{\circ}\right)$ on August 28 and should be looked for in the early morning at about this date. Venus continues as a morning star rising in the dawn at $3 \mathrm{~h} .26 \mathrm{~m}$. on August 1 and at $4 \mathrm{~h} .38 \mathrm{~m}$. on August 25. Saturn reaches a stationary point on August 14, Mercury on August 20, Mars on August 24 and Uranus on August 28. The minor planet Juno is in opposition on August 19, when its magnitude is 8.3 ; on August 1 it is about $50^{\prime}$ south of $\alpha$ Aquarii. The Perseids reach their maximum frequency on or about August 9, their radiant point being near $\eta$ Persei. In the late evenings of mid-August, with the moon absent, the region of the Milky Way near the southern meridian offers interesting 'sweeps' with binoculars or telescope.

\section{Announcements}

Prof. S. Truosnexko, professor of mechanics at Stanford University, California, has been elected correspondant for the Section of Mechanics of the Paris Academy of Sciences.

Mr. R. H. Whitrs, City and Guilds College, London, has been awarded the Busk studentship in aero. nautics for the year 1939-40 tenable at the Aero. nautics Department, Engineering Isaboratory, Cam. bridge.

Trif following awards for 1939-40 have been made by the Salters' Institute of Industrial Chemistry and approved by the Court of the Salters' Company. Fellowships have been renewed in the case of Messrs. A. Cameron (University of Cambridge), H. S. Corran (University of Cambridge) and J. L. Tuck (University of Oxford). Fellowships have been awarded to $R$. Scarisbrick (University of Cambridge), T. WT. Walker (University of London) and J. A. Berriman (University of Cambridge). The Salters' Institute has also awarded forty-four grants-in-aid to young men employed in chemical works in or near London to assist them in their studies.

Prof. Otro Grossern, director of the Anatomical Institute of the German University of Prague, has been awarded the Silver Medal of 1939 by the Jena Society of Medicine and Natural Sciences.

Prof. Esmond R. IJoxa, director of the Henry Phipps Institute and professor of pathology in the University of Pennsylvania, has been elected president of the Wistar Institute of Anatomy and Biology. Dr. Edmond $J$. Farris, associate in anatomy in charge of operations at the Wistar Institute, is to be executive director.

THE twelfth International Congress of the History of Medicine will be held in Berlin on September 22-28, 1940 , when the chief subjects for discussion will be the evolution of medicine in different countries from Harvey to Haller (epoch of medical philosophers) introduced by Dr. Laignel-Lavastine, professor of the history of medicine in the Paris faculty, and the history of typhus, introduced by Prof. Zeiss, director of the Institute of Hygiene of the University of Berlin.

Av nccount of the chemical composition of 'Volpar' contraceptive products recently published (Eugenics Rev., 31, No. 1) gives many details about the nature and action of these substances. They are in the form of gels and pastes and are weakly alkaline, containing phenyl mercuric acetate in aqueous solution. The gels contain also glyceryl monoricinoleate together with a fungicide to prevent the action of bacteria and moulds. The paste contains a basis of arrowroot starch and can be used in the tropies. Numerous tests of their efficiency and other effects have been made on animals. 